\title{
TIMOTHY MORTON: \\ HYPEROBJECTS, PHILOSOPHY AND ECOLOGY \\ AFTER THE END OF THE WORLD \\ (RECENZIÓ)
}

\section{A recenzió szerzője:}

Vályi Péter (Drs)

Eszterházy Károly Egyetem

Szerző e-mail címe:

valyipeti@gmail.com
Lektorok:

Mezô Katalin (PhD)

Debreceni Egyetem

Varga Attila (PhD)

Eszterházy Károly Egyetem-OFI

...és további két anonim lektor

Vályi Péter (2019): Timothy Morton: Hyperobjects, Philosophy and Ecology after the End of the World (Recenzió). OxIPO - interdiszciplináris tudományos folyóirat, 2019/4, 79-88. doi: 10.35405/OXIPO.2019.4.79

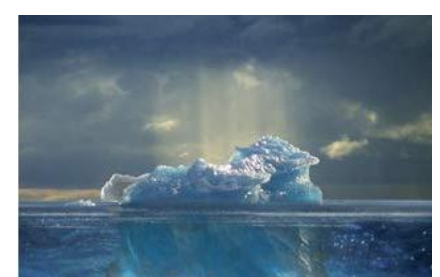

Hyperobjects

Philosophy and Ecology

after the

End of the World

Timothy Morton
A recenzió alapjául szolgáló mü bibliográfiája: Morton, T. (2013): Hyperobjects, Philosophy and Ecology after the End of the World. / Hiperobjektumok, filozófia és ökológia a világ vége után/ Minneapolis: Univerity of minnesota Press. 201 oldal ISBN-10: 0816689237

Kulcsszavak: természet, globális felmelegedés, öko-kriticizmus, pedagógia, környezeti nevelés

Diszciplina: filozófia, ökológia, pedagógia

Bibliography of the subject of this recension: Morton, T. (2013): Hyperobjects, Philosophy and Ecology after the End of the World. Minneapolis: Univerity of minnesota Press. 201. pp. ISBN10: 0816689237

Keywords: nature, global warming, ecocriticism, pedagogy, environmental education

Disciplines: philosophy, ecology, pedagogy 
Az ökológiai válság, azon belül a globális felmelegedés, olyan meghatározó diskurzussá vált napjainkban, amely a természettudományok mellett áthatja egyéb diszciplinák központi témáit is.

A kortárs filozófiai narratívákon belül egy markáns irányzat, az OOO (Objektum Orientált Ontológia), ennek egy nonantropocentrikus keretezését kínálja, amely azt mondja, hogy az objektumok lapos (horizontális) demokráciáját számtalan magasabb rendű, nehezen értelmezhető tárgy teszi áttekinthetetlenné. Ezek a tárgyak egyrészt már léteztek a maguk eredeti formájában (sugárzás, felmelegedés), másrészt ember alkotta jelenségek (kapitalizmus, technológia). Ezek a szuper masszív, nagy kiterjedésű objektumok a hipertárgyak. Morton állítása szerint maguk a hipertárgyak sosem válnak láthatóvá, csak azok a szimptómák, amelyek más tárgyakon keletkeznek a velük való kapcsolatba lépés esetén (Morton 2013).

Jelen recenzió egy három részes sorozat második eleme, amelyben Timothy Morton amerikai kortárs filozófus, teoretikus munkásságának három mûve kerül bemutatásra, illetve keretezésre a pedagógiai kutatás perspektívájából.

Az előző - The Ecological Thought (Morton, 2010) című könyvet ismertető recenzióhoz (lásd: Vályi, 2019) hasonlóan a szöveg írásmódja mindvégig tárgyszerűségre törekszik, leíró jellegű és előre megadott szempontok szerint strukturálódik, a személyes észrevételek kifejtésére, mindössze a „Szubjektív áttekintés, peda- gógiai alkalmazhatóság” fejezetben kerül sor, elsőbbséget adva itt a pedagógiai kutatás, környezeti nevelés szempontjainak a mű felvetéseit, tartalmát illetően.

\section{A szerző}

Timothy Morton amerikai kortárs filozófus, teoretikus, jelenleg a houstoni Rice Egyetem angol tanszékének professzora. Eredeti kutatási szakterülete az angol romantikus lírika, jelenleg objektum orientált, spekulatív realista filozófiával foglalkozik. Ezeken belül az ökológia tárgya, annak etikai, esztétikai dimenziója képezi eddig megjelent hat kötetének központi motívumát. Mûveinek megítélése ambivalens, de függetlenül a kritikai hangoktól, elképzelései, hipotézisei gyorsan terjednek és számos filozófiai, tudományos, képzőművészeti, pedagógiai projekt elméleti háttereként szolgáltak, illetve szolgálnak napjainkban is.

\section{A kiadvány témája}

Morton sorban harmadik, 2013-ban megjelent könyvében, a Hyperobjects, Philosophy and Ecology After the End of the World címúben, egy az előző írásának utolsó fejezetében bevezetett terminus kifejtésére tesz kísérletet. A The Ecological Thought (Morton, 2010) harmadik, Forward thinking címú fejezetében a furcsává, idegenné tett világ ökologikus megélését, megértését számos nagy kiterjedésű, masszív objektum teszi még zavarosabbá. 
Ezek az emberi érzékelés, értelem számára relatív, láthatatlan objektumok, a továbbiakban hipertárgyak, magasan az ember alkotta tér-idő fogalom felett helyezkednek el. Keletkezésük, vonatkozásában fontos megjegyezni, hogy számos formában már léteztek a mortoni ,világvégét” (nem geológiai, biológiai, hanem ontológiai) megelőzően (például: agrologisztika, földi sugárzás, globális hőmérsékletnövekedés). Azonban a 150-200 éves intenzív emberi terraformálás következtében egyrészt az emberiség új hipertárgyakat hozott létre (kapitalizmus, technológia, mûanyag), másrészt a már meglévő hipertárgyak intenzitását is növelte ezek által (globális felmelegedés, sugárszennyezés). Morton értelmezésében az a pont, amely óta a hipertárgyak dominanciája a Földön megkérdőjelezhetetlen, illetve magának a földi életnek legfőbb veszélyforrásai, maga a „világvége”, egyben egy új kor, a hipertárgyak korának kezdete.

A könyv a hipertárgyak leírására öt központi fogalmat, minőségi kategóriát nevez meg, amelyek a következők: non-lokalitás, viszkozitás, időbeli hullámzás, interobjektivitás, fázisosság, amelyeknek a bővebb kifejtésére a „Főbb témakörök” című bekezdésben térek ki.

Amellett, hogy Morton keretezi saját hiper-tárgy elméletét, a „világvége” heideggeri fogalmát (Heidegger, 1927, Musanovic, 2014), az azokkal való szembesülés folyamatának (pszichológiai, élettani) leírására is kísérletet tesz, amelyet három formában ír le, tagadás, gyengeség, bénultság. A könyv nem zöld forradalomra lelkesít, amelyek célja a hiper-tárgyak „legyőzése”, ellenkezőleg, ahogy az, az öt minőségi kategóriából is kiderül, a könyv a hipertárgyakkal szembeni magatehetetlenségről szól, arról, hogy a létezésük, így létezésünk a jövőben elképzelhetetlen azok tudatos integrálása nélkül, amelyre a politikának adekvát válaszokat kell adnia.

Morton nem túloz akkor, amikor azt mondja, hogy Stonehenge nem létezett 10 000 évvel ez előtt, a polisztirol viszont 10 000 év múlva is létezni fog, ezért, ha az emberiség földi létezésének hagyatékaira, emlékeire gondolunk, gondoljunk egészen nyugodtan a hipertárgyakra is, amelyek nem kizárt, hogy az emberiség utolsó hagyatékaivá is válnak (Morton, 2010, 2013).

\section{A kiadvány jelentősége, aktualitása}

A szerző alakja, egyben maga a kiadvány megkerülhetetlen eleme a napjainkban kulmináló, politikai, ökológiai közbeszédet tematizáló antropocénnek. Lévén, hogy a globális válság fenyegetése a könyv kiadását követően 2019-ben nem enyhült (IPCC 2019), mindinkább erősödött, helye az ezzel foglalkozó tudományos diskurzusban vitathatatlan, mert annak egy új non-antropocentrikus (Márkus, 2018) megközelítését kínálja. Morton hipertárgy elmélete inspirálta a „non place based” padagógia irányzatát, amely kimondottan a hipertárgyak generálta non-lokalitásra, időbeli hullámzásra, interobjektivitásra építi környezeti pedagógia koncepcióját 
(Saari, 2017, Saari és Mullen, 2018). Bár némi idő elteltével, de a nemzetközi pedagógiai kutatások, gyakorlatok elkezdték Morton felvetéseinek interpretálását annak érdekében, hogy új perspektíván keresztül váljon egy mindenkit érintő globális téma feldolgozhatóvá.

\section{A kiadvány szerkezete}

Morton harmadik kötete sem terjedelem, sem írói stílus vonatkozásában nem mutat jelentős eltérést az ezt megelőző írásaihoz képest, a szöveg, ahogy eddig is, gazdag háttéranyagból merít, eklektikusan, bátran destruál, illetve helyez egymás mellé magas és popkulturális, tudományos elemeket (kvantumfizika, relativitás és Csillagok háborúja szintetizálása). A LARB-on (Los Angeles Review of Books) olvasható egy kritika, amelyben a szerző a mash-up, (azaz több elemből összerakott, barkácsolt zenei mû) kifejezéssel illeti a könyvet, ami tekintettel a cikázó és gazdag referenciális háttérre teljesen meg is állja a helyét (Los Angeles Review of Books, 2014).

A mû három nagy témakörre osztható. A bevezető fejezet, amelynek címe A Quake in being, An Introduction to Hyperobjects, azaz Rengés (megremegés) a létezésben, Bevezetés a Hipertárgyakhoz az ontológiai változásról, a XX. századi nagy filozófiai irányzatok (strukturalizmus, posztmodern, episztemológia) által hátrahagyott félkész munka befejezésének a szükségszerűségégről beszél, amelyet az OOO, azaz Objektum Orientált Ontológia lesz képes elvégezni. A első fejezet What are Hyperobjects?, a hipertárgyak immanens, és egymástól elválaszthatatlan permanens tulajdonságainak a leírására tö-rekszik, öt fogalom/minőségi kategória leírása mentén. A második fejezet a The Time of Hyperobjects a Hiprtárgyak kora, a hipertárgyak és az emberi és nem emberi lények találkozásának a diagnosztizálása. Egyfajta meditáció, ráhangolódás a világ hiányára (vesd össze: Morton, 2013, Musanovic, 2014).

\section{Főbb témakörök}

A hipertárgyak megértését, leírását szolgáló öt minőségi kategória.

\section{Nonlocality}

A non-lokalitás a térben és időben való elhelyezhetőség problémájáról beszél, (ezért sokkal inkább egyfajta eloszlásról van értelme beszélni) ennek értelmében minden látható jel, minden szimptóma, csak egy múltbéli találkozás lenyomata csupán, amely a (szubjektív, objektív) történelem egy darabja, a hipertárgy egy aspektusa és nem maga a hipertárgy (Morton, 2013). Magát a globális felmelegedést nem látjuk, csak annak időjárásban tapasztalható radikalizálódó jelenségeit.

Viscosity 
A ragadás, tapadás a non-lokalitással ellentétben a hipertárgyak ragacsos közelségének a leírása. A tárgyak a téves elképzelések ellenére nem válnak le egymásról, illetve nem semlegesek egymás számára. Láncolatot, rendszert alkotnak, más tárgyakhoz hasonlóan hozzánk emberekhez is kapcsolódhatnak (Morton, 2013). Példának okáért a leégés, az emberi testet borító hámréteg sérülése.

\section{Temporal Undulation}

Az időbeli hullámzás a hipertárgyak transzcendentáló jellegének leírása, amely az eltűnés-feltűnés problematikája is egyben térben és időben. A hipertárgyakat egyfajta relativitás jellemzi, amely az elméleti fizika időre és térre alkotott relativitásához hasonlatos (Morton 2013).

\section{Phasing}

A hipertárgyak láthatatlanok a maguk teljességében az ember három dimenzióra épített világában. Morton azt mondja, hogy egy olyan magasabb dimenzióban terülnek szét, amely érzékelése meghaladja az azt érzékelő képességek (fül, orr, szélkakas) lehetőségeit. Ebből adódóan a hipertárgyak metonímiáit hozzuk létre, nem magáról a hipertárgyról, hanem annak érzékelhető megnyilvánulásáról beszélünk.

\section{Interobjectivity}

Morton objektum orientált értelmezésében az ember, mint szubjektum is egy tárgy, tehát objektummá válik, amely meg- fosztatott minden eddig őt megillető emberi privilégiumától. Az interobjektivitás így nem más, mint az egyes objektumok más objektumokban való megjelenése, visszatükröződése (Morton, 2013).

Graham Harman szerint a tárgyak önmagukban eleve megismerhetetlenek, csak más tárgyakon keresztül válnak megtapasztalhatóvá (Harman, 2012). A globális felmelegedés transzcendens jelenléte az időjárásban, majd az időjárás transzcendens jelenléte a mezőgazdaságban.

\section{Szubjektív áttekintés, pedagógiai alkalmazhatóság}

Ahogy az előző áttekintés esetében, úgy most sem azt tartom fontosnak, hogy Morton poszt-kantiánus filozófiával, korrelációval, episztemológiával szembeni kritikájáról, vagy a heideggeri életmű rekonceptualizásáról beszéljek, vagy esetleg tágabb értelemben a Graham Harman által leírt Objektum Orientált Ontológiáról (Harman, 2002, 2005), mert ez evidens módon egy filozófiatudományos vita lehetőségét is megteremtené. Ezek a viták zajlanak is (Shaviro, 2010), ezért úgy gondolom a keretezéshez szükséges háttér megemlítésén túl, sem a terjedelem, sem a diszciplinák közötti átjárás nem enged/kíván meg ennél többet.

Alapvetően elfogadom a könyv azon állítását, amely szerint van számtalan olyan felfoghatatlan (materiális, immateriális) jelenség (hipertárgy) a Földön, ame- 
lyek megismerése a jelenlegi tudományos eszközök által képtelenség. Az OOO azon állitását is elfogadom, hogy a tárgyaknak (objektumoknak) mindig a „felénk néző oldalát" látjuk, amely egyfajta korlátozott ismeretnek feleltethető meg, így valami mindig ismeretlen/rejtve marad, ezért segítség a megismerésben az interobjektivitás, tehát egyik tárgy megismerése egy másik tárgy által. Amellett, hogy egyet tudok érteni a hipertárgy terminus, globális felmelegedésre, kapitalizmusra, radioaktivitásra való alkalmazásával, úgy azok öt minőségi kategóriájával, tulajdonságával sem akarnék vitatkozni. A teoretizálás hiányaként a valódi politikai gyakorlat alulreprezentáltságát, így a demokrácia megváltozott fogalmának kifejtését nevezném meg, vagy azt, hogy a hipertárgyakkal való összekuszáltság könnyedén megteremtheti egyfajta hiperszubjektivitás lehetőségét. Több kritikában is olvasható egyfajta elmarasztalás a valós praxis leírását illetően, amelyek a ködös teoretizálás mellett/helyett konkrétumokra lennének kíváncsik, hipertárgyakkal alkotott közös demokrácia, politika koncepció vonatkozásában (lásd: Critical Inquiry, 2014, Academica.edu, 2017). Mivel Morton világvége utáni állapota nem egyenlő a nagy geológiai, klimatológiai katasztrófaként ábrázolt és erős vizuális effektusok mentén tematizált világvégével, ajánlásai is mások. A hipertárgyak kora nem a Világ 2.0, hanem az a kor, amelyben az emberiség 150-200 éve létrehozott (kapitalizmus, technológia, atomenergia), vagy már meglévő, de emberi tevékenység által befolyásolt globális jelenségek (felmelegedés, sugárzás) válnak dominánssá. A legnagyobb probléma talán az, hogy eddig tévesen azt feltételeztük, hogy „megosztjuk” lakhelyünket ezekkel az emberi cselekvőképesség értelmében passzív entitásokkal, mára azonban egyre nyilvánvalóbbá válik, hogy a bolygón való jelenlétünk sokkal inkább függ ezen entitásoktól és azokhoz füződő viszonyunktól, mint azt eddig cinikus módon feltételeztük.

Mivel a jövőnk elképzelhetetlen a hipertárgyak nélkül, úgy gondolom célszerū kiemelni mindazon, akár pedagógiába, környezeti nevelés elméletbe, gyakorlatba átültethető elképzeléseket, amelyeket Morton hipertárgy elmélete tartalmaz. Az alábbiakban ezeknek a megfogalmazására teszek kísérletet.

- Az oktatás-nevelés, szúkebb értelemben a környezeti nevelés rámutat a globális válság kialakulásáért felelős katalizátorokra (globalizáció, gazdasági növekedés, kapitalizmus), a kritikai pedagógiák, főleg azok, amelyek beágyazottságuk jóvoltából, mély analitikus vizsgálatnak is vetik alá azokat (NKNS, 2018, Critical pedagogy in the new Dark Ages, 2012). A hipertárgy megközelítés lehetővé teszi a jelenségek kvantumszintű elbeszélését, amely képes lehet a függőségi viszony ellentmondásosságának a narrálására, világ és kapitalizmus között, rávilágítva így arra, milyen mélyen 
ágyazódott bele mindennapi dinamikánk, gondolkodásunk a globális gazdasági rendszerbe (Morton, 2013).

- A környezeti nevelés által sürgetett szemléletmódváltás, mint imperatívusz, korán sem olyan nyilvánvalónak tekintendő mint azt feltételezzük, ugyanis magában hordoz egy komoly paradoxont. A-mennyiben elfogadjuk, hogy sem az ökológia, sem a hipertárgyak világában nem létezik helyzeten kívüli, illetve belüliség, úgy azt is el kell fogadnunk, hogy a szemléletmódváltás nem a világ megváltoztatásával egyenlő, hanem azzal, hogy megváltoztatva a helyünket, (jelen esetben szellemi, intellektuális pozíciónkat) elkezdjük másként látni a világot (Mor-ton 2007, 2013).

- A harmadik felvetés Morton hipertárgy elmélete alapján a cselekvő, cselekedtető pedagógia „cselekedj” koncepciójának mélyrehatóbb vizsgálatára helyezi a fókuszt. A cselekvő, vagy cselekedtető pedagógia rendszerint a demokratikus, vagy önkormányzó gyakorlatok iskolai terepe, amelyben a tanulók a közvetlen, vagy közvetett demokrácia eszközeivel szimbolikusan, vagy pragmatikusan beavatkoznak a társadalom ügyeibe, előmozdítva ezzel egy magasabb szintű (akár helyi törvénykezéssel is konkuráló) etikai elképzelés megvalósítását (jelen körülmények között egy természeti, környezeti eredetű problémát evidens módon - v.ö.: Jensen és Schnack,
1997). Morton hipertárgyként azonosított jelenségei messze az ember, térbeli és időbeli keretrendszere fölött léteznek, azt is mondhatjuk relatívak (gondoljunk itt a radioizotópok felezési idejére, műanyagok, egyéb fizikai szennyezők lebomlásának idejére, vagy akár az iparosított területek rekultivációs idejére). Morton helyesen érvel akkor, amikor azt mondja, hogy maga a radioaktív szennyezettség, műanyag, globális felmelegedés nem szűnik meg a különböző környezetvédelmi gyakorlatok által, mindössze azok szimptómái válnak fizikai értelemben érzékelhetővé, kezelhetővé. A valódi probléma mindvégig rejtve marad. Legyen a cselekvés bármilyen jó szándékú a forrást képtelenség megszűntetni, mert az, az emberinek nevezett dimenzió felett létezik (Morton, 2013).

- Végezetül az utolsó, egyben előremutató felvetés az elfogadás, beletörődés és környezeti nevelés problémája, amely felvetés leginkább a pedagógiai etika kérdéskörébe tartozik véleményem szerint. Ahogy az a Fenntarthatóság pedagógiájában (Jakab és Varga, 2007) a cselekvő pedagógia vonatkozásában kifejtésre kerül, a katasztrófapedagógia helytelen módja a komplex globális válság tanórai interpretációjának. A kérdés, amely azon-ban felmerül, hogy a pedagógia árnyalhatja-e a valóságot, illetve építhet-e idealizált, naiv képet a cselekvés, egyéni 
cselekvés nyilvános, egyben globális térben (!) alkalmazható potenciáljáról. A félreértés elkerülése véget, itt nem a cselekvő pedagógia léte, nem az alapkoncepciója kérdéses számomra, hanem a pedagógiai, politikai, pszichológiai motívum, amely alkalmazását szorgalmazza. Kétséget kizáró módon szeretném leszögezni, hogy a felvetésem nem a felelősségteljes, tudatos életmód implicit kritikája, amelyet igen, iskolai akciók formájában meg lehet ismerni, el lehet sajátítani, hanem a cselekvés túldimenzionált interpretációjával szembeni kétség.

\section{Az OxIPO-modell}

\section{és a Hipertárgy elmélet}

A Hipertárgy elmélet egyrészt önálló koncepció, tágabb kontextusban Morton poszt-kantiánus tudományfilozófiával szembeni kritikájának a szerves része, amely a tudományos adatszerzés, ismeretszerzés, tanulás folyamatát is érinti. Röviden a végesség fogalmának tagadása (Morton, 2018). Az OxIPO-modell produktív tanulási stratégiája egy generatív/öngeneráló tanulási folyamat, amely során egy ismeret újabb ismeretek előhívását, kapcsolását jelenti, kreatív kapcsolás/társítás által (Mező és Mező, 2019). Morton kvantumszintű objektumorientált ontológiája valóban magában hordozza a hiperszubjektív kogníció veszélyét, de a Hipertárgy elmélet hasonló generatív megismerő-leíró folyamat, amely Morton ökológia felfogásából ered, amelyben egyfajta végtelen összekapcsoltság, egymásrautaltság létezik (Morton, 2010). Véleményem szerint a két modell, tehát produktív tanulási stratégia és ontológia nagyon is hasonló, illetve egymással könynyen kombinálható egyfajta hiperpedagógia, vagy hipertanulás formájában, amely egy bemeneti jel alapján egy horizontálisan szétterülő ismereti hálót hozhat létre (Morton, 2010). Példa, egyben segítség lehet a tanulási módszer megértésére Morton egy 2011-es video előadásának részlete, amelyben egy tajvani bambusz erdő részlete látható, a narráció pedig az alábbi szöveg: „Amit nézel az a szél a bambuszok hajtásai között, vagy maguknak a bambusz ágaknak a csattanó egymásnak ütközése a szél hatására. Vizuális és audiális jelek egy bizonyos fordítása egy rövid videó formájában, de az is lehet, hogy a Nap visszatükröződő fotonjai a kloroplasztiszon, amely zölddé teszi a bambuszt. Amit nézel azok a kloroplasztiszok által elnyelt baktériumok, amelyek rejtve maradtak a környezeti kataklizma elől, így közreműködhettek az oxigén létrejöttében másfél billió évvel ezt megelőzően.” (Morton, 2011).

\section{Ajánlás}

A könyvet bátran ajánlom azoknak, akik a pedagógiai praxisukban a globális felmelegedés, vagy egyéb globális jelenségek elbeszélésével foglalkoznak, vagy szeretnének foglalkozni. Bár nem egyszerű, Mor- 
ton főként Heidegger, Kant és Harman filozófiai munkásságára építő érvelése és gondolatmenete, de az értelmezési nehézségek ellenére tartalmaz interpretálható és alkalmazható eszközöket a szóban forgó jelenségek tanórai feldolgozásához, illetve képezheti tanórai kutatómunka, akció témáját is.

\section{Irodalom}

Critical Pedagogy in the Dark New Ages: Challenges and Possibilities (2012) Pter Lang Inc.

Harman, G. (2002): Tool-being, Heidegger and the Metaphiycs of Objects, Open Court, USA

Heidegger, M. (2019): Lét és idô. Osiris, Budapest

Heise, K. U. (2014): Timothy Morton's Hyperobjects on Critical Inquiry. Letöltés: 2019.10.24. Web: https://critical inquiry.uchicago.edu/ursula_k._heise_ reviews_timothy_morton

Giepert, C. (2017): Review of Timothy Morton Hyperobjects, Dark Ecology, Humankind. Letöltés: 2019.10.24. Web: https://www.academia.edu/37152895 /Review_of_Timothy_Morton_Hyper objects_Dark_Ecology_and_Humanki nd)

Mező Ferenc és Mező Katalin (2019): Az OxIPOmodell - az interdiszciplináris kutatások egy lehetséges értelmezési kerete. OxIPO - interdiszciplináris tudományos folyóirat, 2019/1, 9-21. doi:
10.35405/OXIPO.2019.1.9 Letöltés: 2019.11.06. Web: http: //www.kpluszf.com/assets/docs/OxI PO/OxIPO_2019_1_09_Mezo_Mezo .pdf

Morton, T. (2010): The Ecological Thought. Cambridge, USA: Harvard University Press. doi: 10.2307/j.ctvihzskj

Morton, T. (2013) Hyperobjects, Philosophy and Ecology After the End of the World. Minneapolis: Univerity of Minnesota Press

Morton, T. (2007): Ecology without Nature, Rethinking Environmental Easthetics. Cambridge: Harvard University Press

Musanovic, A. (2014): Meditations in Midair Letöltés: 2019.10.25. Web: https://www. academia.edu/8724539 /Meditations_in_Midair_A_review_es say_of_Timothy_Morton_Hyperobjec ts_Philosophy_and_Ecology_after_th e_End_of_the_World)

Muecke, S. (2014): Global Warming and other Hyperobjetcts on LARB. Letöltés: 2019.10.24. Web: https://lareviewof books. org/article/hyperobjects/

Jakab Gy. és Varga A. (2012): Fenntarthatóság pedagógiája. L'Harmattan Kiadó, Budapest

Jensen, B. B. \& Schnack, K. (1997): The Action Competence aaproach in environmental education. Letöltés: 2019.10.24. Web: https://www.ensi. org/global/downloads/Publications/4 05/Jensen $\% 20$ Action $\% 20$ Competence $\% 20$ Approach $\% 20 \mathrm{in} \% 20$ Environmen tal\%20Education.pdf 
Saari, A. (2017): A Dark Education: Environ-mental Education research in a World of Hyperobjects. Letöltés: 209.10.25.Web: https://www. youtube $. \mathrm{com} /$ watch?v=3MasMdHcQyMn

Saari, A. \& Mullen, J. (2018): Dark places: environmental education research in a world of byperobjects. Letöltés: 2019.10.24. Web: https://www.researchgate.net/ publication/328704588_Dark_places_ environmental_education_research_in _a_world_of_hyperobjects

Vályi Péter (2019): Timothy Morton: The Ecological Thought (Recenzió). OxIPO - interdiszciplináris tudományos folyóirat, 2019/ 3,95-101. doi: 10.35405/OXIPO.2019.3.95 Letöltés: 2019.11.06. Web: http://www. kpluszf.com/assets/docs/OxIPO/Ox IPO_2019_3_095_Valyi.pdf 